dowe i państwowe. Autorka przedstawia kolejne koncepcje w wymiarze teoretycznym oraz praktycznym - ukazując konkretne osoby i instytucje, które wprowadzały je w życie. Wśród wielu stowarzyszeń szczególna uwaga została poświęcona Polskiej Macierzy Szkolnej i jej rozległej działalności na gruncie oświatowo-opiekuńczym.

Dwa ostatnie rozdziały zapoznają Czytelnika z praktycznymi stronami funkcjonowania organizacji opiekuńczo-wychowawczych. W czwartym zaprezentowano podstawy ekonomiczne ich funkcjonowania. Badając materiały archiwalne kilkudziesięciu wileńskich organizacji, autorka ukazuje różnorodność rozwiązań w pozyskiwaniu środków oraz zarządzaniu majątkami, a także trudności w tym zakresie, spowodowane choćby kryzysem ekonomicznym.

Ostatni rozdział poświęcony jest członkom i władzom towarzystw opiekuńczo-wychowawczych, którymi w większości byli społecznicy i filantropi. Oprócz wymienienia najbardziej zasłużonych działaczy ukazana zostaje struktura i różnorodne zasady funkcjonowania wileńskich organizacji dobroczynnych.

Praca Aleksandry Siedlaczek-Szwed nie wyczerpuje oczywiście tematu instytucji dobroczynnych na Wileńszczyźnie, ponieważ z uwagi na bogate tradycje w tej dziedzinie, niejedna $z$ omawianych organizacji wymagałaby sporządzenia oddzielnej monografii. Czytelnik ma okazję zaznajomić się z dużym zróżnicowaniem, jakie w Polsce międzywojennej występowało wśród organizacji zajmujących się pomocą potrzebującym oraz charakterystycznymi dla Ziemi Wileńskiej problemami politycznymi i narodowościowymi. Trzeba podkreślić duży wkład pracy Autorki w uporządkowanie materiału - zaprezentowanie zawartości zasobów archiwalnych oraz wielu czasopism, dzięki którym jest możliwa rekonstrukcja jakże chlubnych działań polskich filantropów. Warto również oczekiwać kolejnych publikacji dotyczących organizacji dobroczynnych, które często - mimo wielu lat swojej działalności - nie zostały jeszcze ujęte w opracowaniach historycznych.

Mikołaj Brenk

\title{
Władysława Szulakiewicz, Historia wychowania w Uniwersytecie im. Adama Mickiewicza, Warszawa 2007, ss. 47
}

Historia wychowania jest swoista dyscyplina stykowa, która oscyluje [...] zarówno $w$ aspekcie organizacji nauki, jak $i w$ wyborze problematyki naukowo-badawczej oraz warsztatu naukowo-badawczego itp., bardziej ku pedagogice niz ku historii ${ }^{1}$. Jej początki sięgają XIX w. i co warto podkreślić, związane są z Poznaniem (!). W 1841 r. po raz pierwszy wydano w Poznaniu Stan oświecenia $w$ Polsce $w$ ostatnich latach panowania Augusta III (1750-1764) Hugo Kołłątaja, którego uważa się - dość powszechnie - za

\footnotetext{
${ }^{1}$ J. Hellwig, Dzieje historii wychowania w Polsce i jej twórcy, Poznań 2001, s. 10.
} 
ojca polskiej historiografii, a także za twórcę historii wychowania ${ }^{2}$. Intensywny rozwój naukowo-badawczy z zakresu historii wychowania na Uniwersytecie im. Adama Mickiewicza można datować od powstania Zakładu Historii Wychowania - 1 września 1967 r.

Władysława Szulakiewicz w swojej książce Historia wychowania w Uniwersytecie im. Adama Mickiewicza przedstawiła rys historyczny działalności poznańskich historyków wychowania. Praca ta zasługuje na szczególną uwagę, gdyż Autorka na tle rozwoju historii wychowania w Polsce, scharakteryzowała powstawanie i rozwój historii wychowania w Poznaniu. Zadaniem niniejszego tekstu jest, co podkreśla we „Wstępie” Autorka, ukazanie ogólnych tendencji $w$ rozwoju tej dyscypliny $w$ okresie od powstania Wszechnicy Piastowskiej, po dzień dzisiejszy, tj. do roku 2007³.

Praca składa się ze dwóch części. W pierwszej, Autorka ukazała wpływ poznańskich badaczy okresu międzywojennego, m.in. A. Danysza, B. Nawroczyńskiego, S. Tynca, L. Jaxy-Bykowskiego, L. Posadzego i innych, na kształt prowadzonych badań z zakresu historii wychowania - nie można mówić wówczas jeszcze o poznańskiej szkole historyków wychowania, ponieważ nie istniała jednostka naukowa skupiajaca pracowników naukowych i dydaktycznych $w$ dziedzinie historii wychowania 4 . Druga część pracy dotyczy rozwoju historii wychowania w latach 1945-2007. Autorka głębszą refleksję poświęciła okresowi stabilizacji poznańskiej historii wychowania ${ }^{5}$, czyli działalności zakładu od roku 1967. Przedstawiła postaci i problematykę badawczą nestorów poznańskiej historii wychowania, prof. S. Michalskiego i J. Hellwiga. Dokonała również charakterystyki głównych nurtów badawczych obecnych pracowników Zakładu Historii Wychowania Wydziału Studiów Edukacyjnych UAM: prof. W. Jamrożka, prof. D. Żołądź-Strzelczyk, dr E. Głowackiej-Sobiech, dr J. Gulczyńskiej, dr K. Ratajczaka, dr K. Kabacińskiej. W. Szulakiewicz podkreśliła słuszność inicjatyw podejmowanych przez środowisko poznańskich historyków wychowania. Zaakcentowała nowatorstwo podejmowanych tematów konferencji naukowych, a także uznała „Biuletyn Historii Wychowania” wydanej przez ZHW za profesjonalne, choć najmłodsze, pismo historyczno-oświatowe.

Książka W. Szulakiewicz jest cenną próbą całościowego spojrzenia na początki, rozwój i współczesną pozycję poznańskiej historii wychowania. Autorka dokonała wieloaspektowej analizy działalności naukowej, badawczej, dydaktycznej i organizacyjnej poznańskich historyków wychowania, odwołując się do licznie zebranej bibliografii. Jej opracowanie ma układ chronologiczny, spójny i logiczny. Przeznaczona jest nie tylko dla środowiska historyków wychowania, ale także dla studentów i każdego, komu bliski jest rozwój nauki.

Katarzyna Kabacińska

\footnotetext{
${ }^{2}$ W. Jamrożek, W czterdziestolecie Zakładu Historii Wychowania, w: Ad novum fructum. Z okazji jubileuszu poznańskich historyków wychowania, pod red. W. Jamrożka, K. Ratajczaka, D. Żołądź-Strzelczyk, Poznań 2007, s. 13.

${ }^{3}$ W. Szulakiewicz, Historia wychowania w Uniwersytecie im. Adama Mickiewicza, Warszawa 2007, s. 8.

${ }^{4}$ Ibidem, s. 15.

${ }^{5}$ Ibidem, s. 21.
} 